\title{
The Mediating Role of Consumer Satisfaction in the Relationship between Brand Equity and Brand Loyalty based on PLS-SEM Model
}

\author{
Shen Lei ${ }^{1} \&$ Luo Chu ${ }^{1}$ \\ ${ }^{1}$ Glorious Sun School of Business and Management, Donghua University, Shanghai, P.R.C \\ Correspondence: Luo Chu, Glorious Sun School of Business and Management, Donghua University, No. 1882, \\ West Yan'an Road, Shanghai, 200051, P. R. C. Tel: 86-158-2116-0873. E-mail: luochu66@126.com
}

Received: November 19, 2014

Accepted: December 10, 2014 Online Published: January 25, 2015

doi:10.5539/ibr.v8n2p62

URL: http://dx.doi.org/10.5539/ibr.v8n2p62

\begin{abstract}
This paper implements a PLS-SEM model to investigate the relationship between brand equity, consumer satisfaction and brand loyalty. Based on a sample of 1840 Chinese sports brands customers, the findings of the model testing confirm that perceived quality, perceived value of cost and price premium are significant dimensions of brand equity. Among these three, perceived value of cost is the most important. The findings also suggest that behavioral loyalty and attitudinal loyalty are effective on brand loyalty, and attitudinal loyalty has more positive influence on brand loyalty than behavioral loyalty does. The current research indicates that brand equity has a positive relationship with consumer satisfaction, and consumer satisfaction has a positive influence on brand loyalty. Further, this study reveals that brand equity has positive influence on brand loyalty partially mediated by consumer satisfaction.
\end{abstract}

Keywords: PLS-SEM, brand equity, customer satisfaction, brand loyalty

\section{Introduction}

Brands are one of the vital assets of a firm (Keller \& Lehmann, 2003; Lehmann \& Srinivasan, 2014). Brand equity has been one of the most important marketing concepts in both academia and practice (Srinivasan et al., 2005). By the 1980s, marketing researchers discovered brand equity had an influence on customer satisfaction (Lanza, 2008). For many years, customer satisfaction has been a major goal of business organizations (Hansemark \& Albinsson, 2004). Brand loyalty describes marketing phenomena, and is typically associated with customer satisfaction (Bennett, 2001). Although scholars often study brand equity, brand loyalty and consumer satisfaction issues, only a few of them have focused on the relationship of brand equity, consumer satisfaction and brand loyalty in recent years (for example, Shen \& Luo, 2012; Nam et al., 2011). Using partial least squares structural equation modeling approach (PLS-SEM) statistical methods and taking advantage of first-hand data from 1840 Chinese sports brands customers, the aims of this study are: confirming the significant dimensions of brand equity and main factors influencing brand loyalty; investigating the relationship between brand equity, consumer satisfaction and brand loyalty.

\section{Literature Review}

\subsection{Brand Equity}

Brand equity is a widely studied topic. While different definitions of brand equity have been offered over the years, many of them are consistent with Farquhar's (1989) definition of brand equity as the value added by the brand to the product (Park \& Srinivasan, 1994). Brand equity can be considered from three different perspectives - customer-based, product-market, and financial-based. From the customer-based perspective, brand equity reflects how customers perceive and react differentially to a branded versus an unbranded offering (Lehmann \& Srinivasan, 2014). From the product-market perspective, brand equity is the enhanced performance in terms of sales and revenue of a branded offering compared to an equivalent unbranded one (Lehmann \& Srinivasan, 2014). From the financial-based perspective, brand equity represents the value of an asset that can be traded and can be thought of as the net present value of anticipated future purchases of the brand (Lehmann \& Srinivasan, 2014).

This paper focuses on the customer-based perspective because customer-based brand equity estimates the consumers' overall intangible assessment of a brand, which is also the driving engine of the incremental financial 
value that accrues to a firm (Rust et al., 2004; Vogel et al., 2008). Aaker (1991) and Keller (1993) have received much attention in the research on discussing the sources of brand equity. Keller (1993) makes a rough outline and views brand equity as brand knowledge, consisting of brand awareness and brand image. According to Aaker (1991, 1996)'s framework, the brand equity is divided into five dimensions: brand loyalty, brand awareness, perceived quality of the brand and brand associations and other brand assets, which have come to dominate the empirical research. Further in this perspective, more universal models have been developed because Aaker's framework is more easily measured and more practically useful (Yoo \& Donthu, 2001; Netemeyer et al., 2004). An extensive literature search suggests that empirical studies have focused on specific products or services because general models are less applicable when attempting to gain some deep insights into specific categories or industries (Lassar et al., 1995; Washburn \& Plank, 2002; Anselmsson et al., 2007; Boo et al., 2009).

\subsubsection{Perceived Quality}

Perceived quality is a brand association at a higher level of abstraction than any specific attribute elevated to the status of a brand asset, represents a consumer's judgments regarding brands' overall superiority/excellence, and provides a surrogate variable for other more specific elements of brand equity (Zeithaml, 1988; Aaker, 1991, 1996; Keller, 1993, 1998). Netemeyer (2004) views perceived quality as the customer's judgment of the overall excellence, esteem, or superiority of a brand (with respect to its intended purposes) relative to alternative brands. Perceived quality is widely considered a "core/primary" facet across customer-based brand equity frameworks because it has been associated with price premium, brand choice, brand purchase intent and brand loyalty (Aaker, 1996; Dyson et al., 1996; Farquhar, 1989; Keller, 2011). The first hypothesis stating this is:

H1: Perceived quality is a significant dimension of brand equity.

\subsubsection{Perceived Value of Cost}

Perceived value is widely defined as an evaluation of the desirability of a product (or service) on the basis of the perceived worthiness of the trade-off between the product's costs and benefits (Tzeng, 2011). For example, A definition Netemeyer (2004) views perceived value of cost as the customer's overall assessment of the utility of the brand based on perceptions of what is received (e.g., quality, consumer satisfaction) and what is given (e.g., price and nonmonetary costs) relative to other brands. While such trade-offs are most commonly represented by a ratio or comparison between quality and price (Cravens et al., 1988; Monroe, 1990), it has been argued that many other factors also help to determine how value is perceived (e.g., Bolton \& Drew, 1991; Sweeney \& Soutar, 2001). Perceived value of cost is considered as a cornerstone of most customer-based band equity frameworks (Farquhar, 1989; Keller, 1993; Aaker, 1996), which occurs at various stages of the purchase process, including the prepurchase stage (Woodruff, 1997). Perceived value of cost is widely accepted because consumer choice of a brand depends on a perceived balance between the price of a product and all its utilities (Lassar et al., 1995). The corresponding hypothesis tested is:

$\mathrm{H} 2$ : Perceived value of cost is a significant dimension of brand equity.

\subsubsection{Price Premium}

Plenty of research suggest that price premium is the most useful and profitability driving measure of brand equity (Aaker, 1996; Sethuraman, 2000). Price premium is the sum consumers were willing to pay for a brand compared to other relevant brands, is an excellent global measure to explain choice of brand at individual level as well as aggregated market shares, which is relatively stable over time but yet captures variations in the brands health. (Aaker, 1996; Agarwal \& Rao, 1996; Ailawadi et al., 2003) In some instances, price premiums refer to dominant firm advantages, while in others, they represent price markups as a result of market concentration, and reflects consumers' willingness to pay an additional amount of money for the extension product in comparison with a private label (or unbranded) product (Hofer et al., 2008; Sattler, 2010). Some writers, such as Doyle (2000) even argue that a price premium is the most important way in which brands create shareholder value. Price premium is included because it reflects the brand's ability to command a higher price than its competitors (de Chernatony \& McDonald, 2003) and is considered important for all types of brands. This allows us to arrive at the following hypotheses of this study:

H3: Price premium is a significant dimension of brand equity.

\subsection{Brand Loyalty}

Brand loyalty has long been a focal point of interest for both scholars and practitioners. Aaker and Keller have different opinions towards the relationship between brand loyalty and brand equity. Aaker believes that brand loyalty, the attachment that a customer has to a brand, is an important component of brand equity, while Keller views loyalty as a consequence of brand equity (Aaker, 1991; Keller, 1993). There are two schools of thought 
measuring brand loyalty: behavioral researchers focus on the observable actions of loyal customers and attitudinal researchers investigate commitment to brands and repurchase intentions (Patterson et al., 1997; Dorsch et al., 2000; Ehrenberg \& Goodhardt, 2000; Kotler \& Armstrong, 2004). This motivated us to develop the corresponding hypotheses of our study as follows:

H4: Behavioral loyalty is effective on brand loyalty.

H5: Attitudinal loyalty is effective on brand loyalty.

\subsection{Consumer Satisfaction}

Customer satisfaction plays a key role in a successful business strategy (Gomez et al., 2004). Customer satisfaction is a complex construct which has been defined in various ways (Dimitriades, 2006). For example, Hunt (1977) conceptualized satisfaction as "an evaluation rendered that the consumption experience was at least as good as it was supposed to be"; Oliver (1996) classifies satisfaction as one of five end-states: satisfaction-as-contentment, satisfaction-as-pleasure, satisfaction-as-relief, satisfaction-as-novelty, and satisfaction-as-surprise. Satisfaction is an affective response to a purchase situation in which satisfied customers are less influenced by competitors, less price sensitive, buying additional products and/or services. (Bagozzi et al., 1999; Zineldin, 2000).

Some authors explored the link between consumer satisfaction and brand equity (Aaker, 1992; Keller, 1993; Anderson \& Sullivan, 1993; Blackston, 2000). In the past, different studies have concentrated on the relationship between consumer satisfaction and brand loyalty, with increases in consumer satisfaction leading to increases in attitudinal brand loyalty (Bolton, 1998; Jones \& Suh, 2000; Bennett, 2001). Since the mediating role of consumer satisfaction has been proved in former work of luxury fashion brands consumption in China by using co-variance based structural equation modeling(CB-SEM), this study takes advantage of first-hand data from 1840 Chinese sports brands customers and uses PLS-SEM statistical methods to prove new model's applicability. This gap leads to propose the following hypothesis of this study.

H6: Brand equity positively influences consumer satisfaction.

H7: Consumer satisfaction positively influences brand loyalty.

H8: Brand equity positively influences brand loyalty.

H9: Consumer satisfaction mediates the influence of brand equity on brand loyalty.

\subsection{Research Model}

The purpose of this research is to investigate the relationship between brand equity, consumer satisfaction and brand loyalty of sports brands consumption in China. As Figure 1 depicts, the study focus on the relationship between brand equity and brand loyalty, and their relationship with consumer satisfaction. The model shall be first estimated without the potential mediator variable consumer satisfaction (H8). In the following step, the mediator variable consumer satisfaction will be included. Here, three dimensions of brand equity, namely perceived quality, perceived value of cost, and brand premium, are assumed to construct the context of brand equity. Measures of brand loyalty consist of behavioral loyalty and attitudinal loyalty.

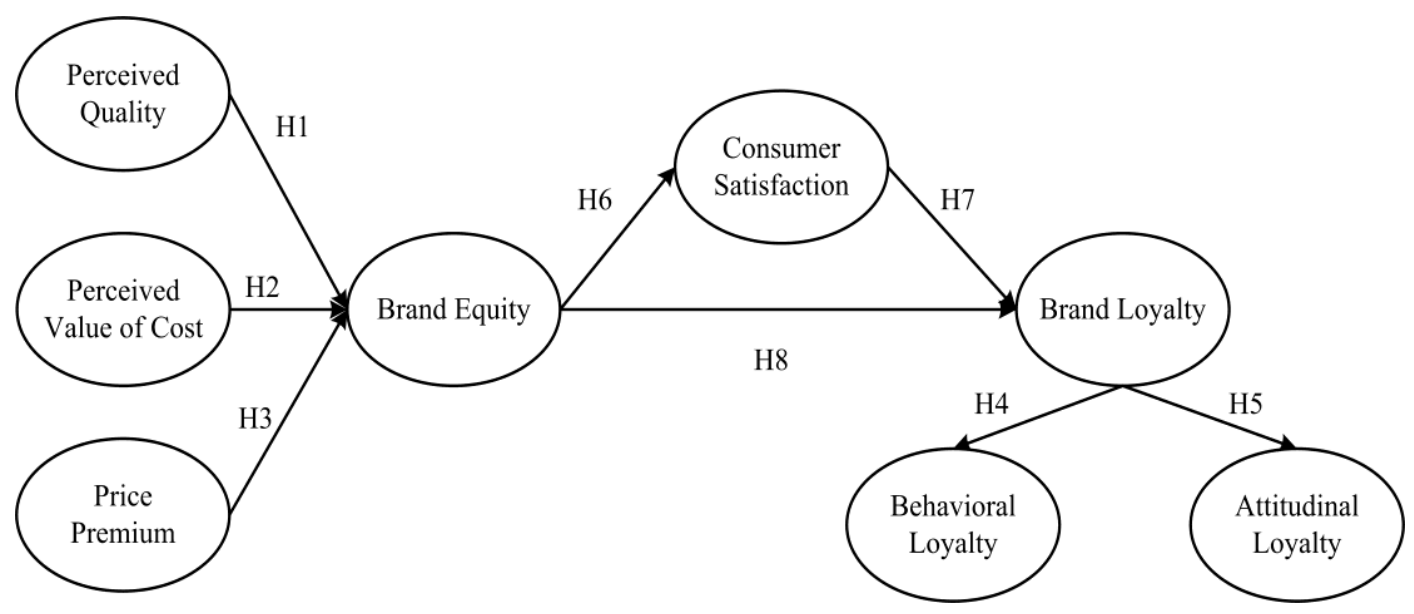

Figure 1. Research model 


\section{Methods}

The study focus on the opinions of consumers towards sports brands: Nike, Adidas, Converse, Mizuno, Asics, Kappa, Puma, Asics, Reebok, Kappa, Umbro, New Balance, Lining (China), Xtep (China), Erke (China), Anta (China), and $361^{\circ}$ (China). This research was conducted in Shanghai, Beijing, Guangzhou, Chengdu, Wuhan and Harbin. The survey was distributed at main shopping malls of these six cities within two months.

First, the survey tested the consumers' brand awareness by adopting Yoo and Donthu's (2001) scale: I am aware of the brand; I can recognize the brand among other competing brands. A total of 2215 respondents were approached, of which 1840 satisfied the criteria of Chinese sports brands customers who passed the brand awareness testing. Then, the questionnaire utilized five-point Likert-type items to measure brand equity, consumer satisfaction, and brand loyalty. The Cronbach's alpha reliability coefficient is 0.749 , higher than 0.7 , indicating satisfactory reliability.

\section{Findings}

\subsection{Descriptive Results}

In the sample, there were $48.6 \%$ males, $51.4 \%$ females, who represented a wide range of ages, which were divided into four age groups (Table 1). The overwhelming majority of the Chinese sports brands consumers are below the age of 46 . Some $67.8 \%$ of them are between 16 and 35 years old, and another $21.1 \%$ are between 36 and 45 years old.

Table 1. Age groups of sample

\begin{tabular}{lcc}
\hline Group & Ages & $\%$ \\
\hline 1 & $16-25$ & 33.5 \\
2 & $26-35$ & 34.3 \\
3 & $36-45$ & 21.1 \\
4 & 46 and over & 11.2 \\
\hline
\end{tabular}

\subsection{Model Testing}

The data collected was analyzed with PLS because it is suitable for predictive applications and theory building, and can easily handle reflective and formative measurement models, as well as single-item constructs, with no identification problems (Gefen et al., 2000; Hair et al., 2013). Our sample size 1840 has exceeded the rule of thumb of 10 times the largest number of structural paths directed at a particular construct in the structural model (Hair et al., 2013). It is therefore applied in our study.

The first step in the analysis is the evaluation of the measurement model (Hair et al., 2013). The t statistic for each cross loading was calculated and in every case, the significance was $p>0.005$, by running a Bootstrap within Smart PLS with 5000 samples using the replacement method. The reliability of single items are greater than 0.70 . Ringle and Straub (2012) suggest that most studies in MIS Quarterly report indicator loadings and measures of internal consistency by reporting Cronbach's alpha, composite reliability, or both, and all studies provide evidence of convergent validity and most models assess discriminant validity. The Composite Reliability is above Henseler's (2009) guideline of 0.6. Discriminant validity is present when the AVE from each construct, calculated by the Fornell-Larcker's (1981) formula, is greater than the square of the inter correlations, constructs, which is the case in our model.

A common argument for using PLS-SEM is that the technique excels at prediction and almost all model estimations use the coefficient of determination $\mathrm{R}^{2}$ values to characterize the ability of the model to explain and predict the endogenous latent variables (Ringle \& Straub, 2012). The Smart PLS algorithm calculated $\mathrm{R}^{2}$ measures for each endogenous variable and the path coefficients for each path within the model. $\mathrm{R}^{2}$ for brand loyalty was 0.544 , which is considered to be moderate (Hair et al., 2011). Whereas $\mathrm{R}^{2}$ for consumer satisfaction was $0.421, \mathrm{R}^{2}$ values of 0.20 are considered high in disciplines such as consumer behavior, in success driver studies (e.g., in studies that aim at explaining customer satisfaction or loyalty) (Hair et al., 2013). The significance of each path coefficient was calculated by bootstrapping with 5000 samples using the replacement method. Thus, we conclude that the model fits the data well.

Using Blindfolding in Smart PLS, $\mathrm{Q}^{2}$ for brand equity was calculated to be 0.1618 , which is a stronger measure 
for model predictive capabilities (Hair et al., 2011; Ringle \& Straub, 2012). The data analysis reveals support for all hypotheses predicted. (Figure 2).

\subsection{Consumer Satisfaction as Mediator}

To begin with, the direct effect is significant when the consumer satisfaction is not included in the model. When including the mediator, the indirect effect is significant. The empirical $t$ value of the indirect effect of brand equity on brand loyalty is 9.5089 , and we can conclude that this relationship via the consumer satisfaction mediator is significant $(\mathrm{p}>0.01)$. The direct effect of brand equity on brand loyalty has a value of 0.376 , while the indirect effect via consumer satisfaction has a value of $0.649 * 0.436=0.283$. Thus, the total effect has a value of $0.376+0.283=0.659$. The VAF equals the direct effect divided by the total effect and has a value of $0.283 / 0.659=0.429$. VAF can have value less than $20 \%$, no mediation and very large outcomes of above $80 \%$, full mediation. A situation in which the VAF is larger than $20 \%$ and less than $80 \%$ can be characterized as partial mediation (Hair et al., 2013). Our conclusion is that consumer satisfaction as a mediator has a moderate effect on brand loyalty, accounting for $42.9 \%$ of the variance.

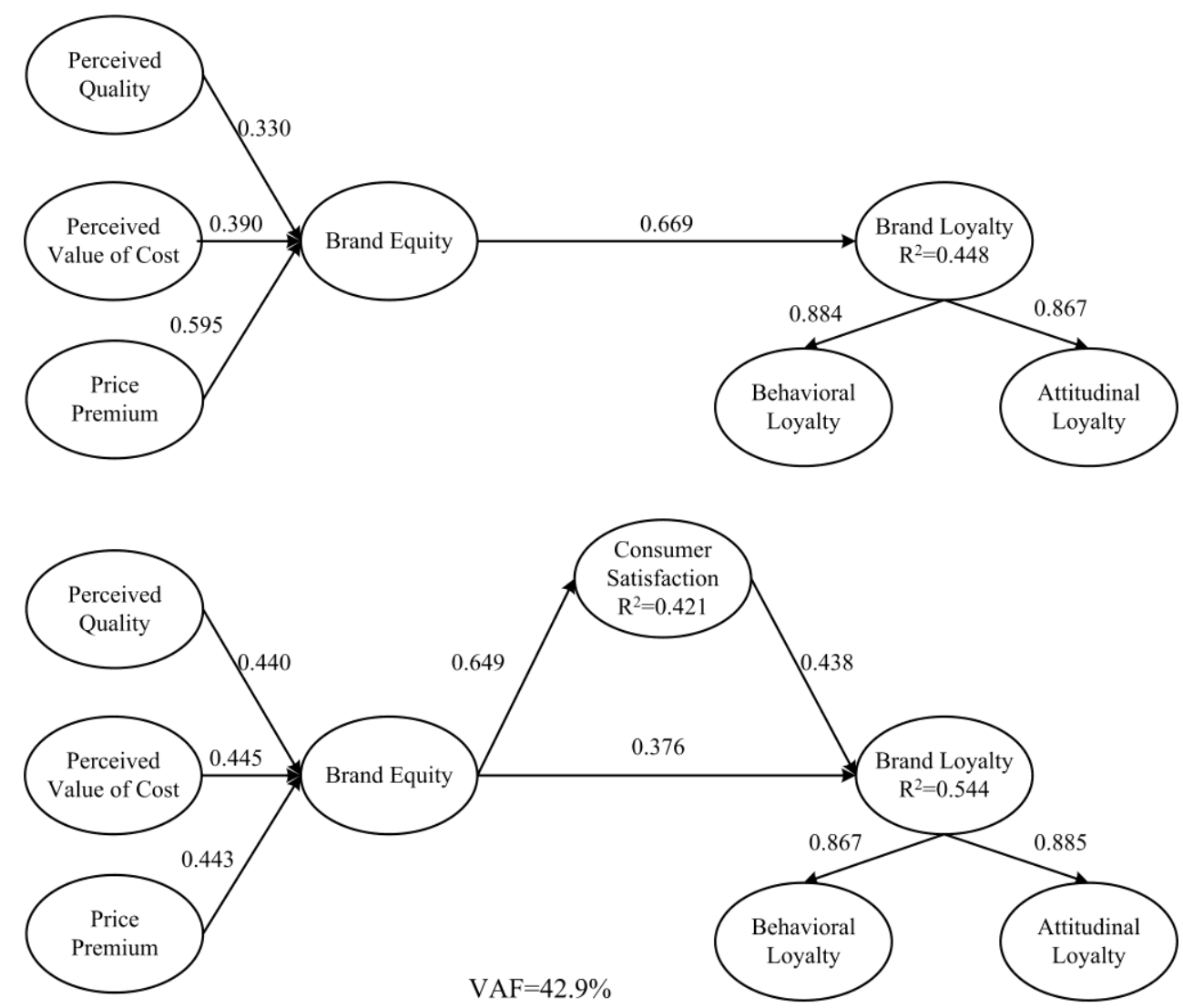

Figure 2. Results of structural equation modeling for conceptual model

\subsection{Support of Hypotheses}

The findings of the model testing confirm that perceived quality, perceived value of cost and price premium are significant dimension of brand equity. Among these three significant dimensions of brand equity, perceived value of cost is the most important. Further, this study confirms that behavioral loyalty and attitudinal loyalty is effective on brand loyalty, and attitudinal loyalty has more positive influence on brand loyalty than behavioral loyalty does. The current research indicates that brand equity has a positive relationship with consumer satisfaction, and consumer satisfaction has a positive influence on brand loyalty. The findings of the model testing reveal that brand loyalty was partially mediated by consumer satisfaction. Hence, the findings of the study support all hypotheses (Table 2). 
Table 2. Support of hypotheses

\begin{tabular}{lc}
\hline H1: Perceived quality is a significant dimension of brand equity. & Supported \\
H2: Perceived value of cost is a significant dimension of brand equity. & Supported \\
H3: Price premium is a significant dimension of brand equity. & Supported \\
H4: Behavioral loyalty is effective on brand loyalty. & Supported \\
H5: Attitudinal loyalty is effective on brand loyalty. & Supported \\
H6: Brand equity positively influences consumer satisfaction. & Supported \\
H7: Consumer satisfaction positively influences brand loyalty. & Supported \\
H8: Brand equity positively influences brand loyalty. & Supported \\
H9: Consumer satisfaction mediates the influence of brand equity on brand loyalty. & Supported \\
\hline
\end{tabular}

\section{Conclusions}

This study provides provide new insights to growing body of literature on brand and related theories. The marketing literature will be enriched upon significant outcomes in four ways.

Firstly, the empirical linkages among consumer-based brand equity, consumer satisfaction, and brand loyalty are significant outcomes to the brand theory because little empirical research studied has explored the same. This study provides a new perspective about the relationship between brand loyalty and brand equity. Previous research suggested that brand loyalty had positive influence on brand equity, while the empirical evidence of our study revealed that brand equity positively influences brand loyalty.

Secondly, the empirical evidence of this study provides a new way to confirm the previous study results. A wide literature didn't have a priority ranking of consumer-based brand equity dimensions. This study reveals that perceived value of cost is the most effective factor to improve consumer-based brand equity, which is in line with the former study done by Shen and Luo (2012) of luxury fashion brands. Moreover, this study uses sports brands which have a larger market than luxury fashion brands (Shen \& Luo, 2012). Based on a sample of 1840 sports brands consumers, this study has a broader adaptability than the previous model of luxury fashion brands.

Thirdly, this study makes contributions to the growing body of literature by examining the effect of customer satisfaction in predicting brand loyalty. This empirical study is the first to examine the influence of consumer satisfaction on the relationship using partial least squares structural equation modeling approach (PLS-SEM). Brand equity is a formative construct which can be appropriately tested by PLS-SEM.

Lastly, this study has found that attitudinal loyalty has more positive influence on brand loyalty than behavioral loyalty does. The results of this study are in line with many theoretical and empirical studies (for example, Shen Lei \& Luo Chu, 2012). Some of the studies have found that behavioral loyalty is influenced by attitudinal loyalty.

\subsection{Limitations and Future Research}

Although the present research adds rigorous empirical evidence to the existing brand management literature, and provides implications to both academicians and practitioners, there are still some limitations which also may create future research options. First, as an exploratory study, this research was only focused on one category of brands. Second, the results didn't provide strong evidence of the universality because it is specific to Mainland China. Although, this research provides some preliminary exploration into the relationships between consumer-based brand equity, consumer satisfaction, and brand loyalty of sports brands, future research may seek to replicate these findings with a border brand categories study and provide further insights into the nature of these relationships between different regions or countries.

\subsection{Managerial Implications}

This study also imparts several managerial implications. China is the world's largest potential consumer market, being the second largest economy and the GDP per capital reached \$700 in 2013. The fast growing of Chinese market is a powerful engine pulling the economies of China and world economy. But on the other hand, after being the world's factory for almost two decades, China's export growth slows, some of the orders from international buyers, including imported products sold on the Chinese market, transfer to the developed countries and the least developed countries because of the increase in Chinese labor and raw material costs, RMB 
appreciation and other factors. Why? The reason lay in our research findings that perceived quality, perceived value of cost and price premium are significant dimensions of brand equity. Sports brands required top quality and high technology. But poor quality, low technology and ugly design of domestic sports brands in mainland China are hurting Chinese consumers. Chinese sports brands lost the biggest market which should have been theirs, and are likely to lose more as long as the Chinese sports brands are the symbol of low quality. The situation is not optimistic for the foreign sports brands, neither. Chinese consumers complain that the domestic and international sports brands' quality standards are not uniformly maintained. Foreign sports brands' prices in the mainland China are much higher than other countries. The lower perceived value of cost, the lower perceived quality, and the lower price premium causes the lower brand equity. The brand equity shrinks, the consumer satisfaction falls. The consumer satisfaction falls, the brand loyalty drops.

\section{References}

Aaker, D. A. (1992). The value of brand equity. Journal of Business Strategy, 13, $27-32$. http://dx.doi.org/10.1108/eb039503

Aaker, D. A. (1996). Measuring brand equity across products and markets. California Management Review, 38(3), 102-120. http://dx.doi.org/10.2307/41165845

Aaker, J. L. (1997). Dimensions of brand personality. Journal of Marketing Research, 347-356. http://dx.doi.org/10.2307/3151897

Anderson, E. W., \& Sullivan, M. W. (1993). The antecedents and consequences of customer satisfaction for firms. Marketing Science, 12(2), 125-143. http://dx.doi.org/10.1287/mksc.12.2.125

Anselmsson, J., Johansson, U., \& Persson, N. (2007). Understanding price premium for grocery products: A conceptual model of customer-based brand equity. Journal of Product \& Brand Management, 16(6), 401-414. http://dx.doi.org/10.1108/10610420710823762

Bagozzi, R. P., Gopinath, M., \& Nyer, P. U. (1999). The role of emotions in marketing. Journal of the Academy of Marketing Science, 27(2), 184-206. http://dx.doi.org/10.1177/0092070399272005

Bennett, R., Härtel, C. E., \& McColl-Kennedy, J. R. (2005). Experience as a moderator of involvement and satisfaction on brand loyalty in a business-to-business setting 02-314R. Industrial Marketing Management, 34(1), 97-107. http://dx.doi.org/10.1016/j.indmarman.2004.08.003

Blackston, M. (2000). Observations: building brand equity by managing the brand's relationships. Journal of Advertising Research, 40(06), 101-105.

Bolton, R. N. (1998). A dynamic model of the duration of the customer's relationship with a continuous service provider: The role of satisfaction. Marketing Science, 17(1), 45-65. http://dx.doi.org/10.1287/mksc.17.1.45

Bolton, R. N., \& Drew, J. H. (1991). A multistage model of customers' assessments of service quality and value. Journal of Consumer Research, 375-384. http://dx.doi.org/10.1086/208564

Boo, S., Busser, J., \& Baloglu, S. (2009). A model of customer-based brand equity and its application to multiple destinations. Tourism Management, 30(2), 219-231. http://dx.doi.org/10.1016/j.tourman.2008.06.003

Cravens, D. W., Holland, C. W., Lamb Jr, C. W., \& Moncrief III, W. C. (1988). Marketing's role in product and service quality. Industrial Marketing Management, 17(4), 285-304. http://dx.doi.org/10.1016/0019-8501(88)90032-6

De Chernatony, L., McDonald, M., \& Wallace, E. (2011). Creating powerful brands. Routledge.

Dimitriades, Z. S. (2006). Customer satisfaction, loyalty and commitment in service organizations: Some evidence from Greece. Management Research News, 29(12), 782-800. http://dx.doi.org/10.1108/01409170610717817

Dorsch, M. J., Grove, S. J., \& Darden, W. R. (2000). Consumer intentions to use a service category. Journal of Services Marketing, 14(2), 92-117. http://dx.doi.org/10.1108/08876040010309220

Doyle, P. (2000). Value-based marketing. Journal of Strategic Marketing, 8(4), 299-311. http://dx.doi.org/10.1080/096525400446203

Ehrenberg, A., \& Goodhardt, G. (2000). New brands: near-instant loyalty. Journal of Marketing Management, 16(6), 607-617. http://dx.doi.org/10.1362/026725700785045912

Fornell, C., \& Larcker, D. F. (1981). Evaluating structural equation models with unobservable variables and measurement error. Journal of Marketing Research, 39-50. http://dx.doi.org/10.2307/3151312 
Gefen, D., Straub, D., \& Boudreau, M. C. (2000). Structural equation modeling and regression: Guidelines for research practice. Communications of the Association for Information Systems, 4(1), 7.

Gomez, M. I., McLaughlin, E. W., \& Wittink, D. R. (2004). Customer satisfaction and retail sales performance: An empirical investigation. Journal of Retailing, 80(4), 265-278. http://dx.doi.org/10.1016/j.jretai.2004.10.003

Hair Jr, J. F., Hult, G. T. M., Ringle, C., \& Sarstedt, M. (2013). A primer on partial least squares structural equation modeling (PLS-SEM). SAGE Publications, Incorporated.

Hair, J. F., Ringle, C. M., \& Sarstedt, M. (2011). PLS-SEM: Indeed a silver bullet. The Journal of Marketing Theory and Practice, 19(2), 139-152. http://dx.doi.org/10.2753/MTP1069-6679190202

Hansemark, O. C., \& Albinsson, M. (2004). Customer satisfaction and retention: The experiences of individual employees. Managing Service Quality,14(1), 40-57. http://dx.doi.org/10.1108/09604520410513668

Henseler, J., Ringle, C. M., \& Sinkovics, R. R. (2009). The use of partial least squares path modeling in international marketing. Advances in International Marketing, 20, 277-319. http://dx.doi.org/10.1108/S1474-7979(2009)0000020014

Hofer, C., Windle, R. J., \& Dresner, M. E. (2008). Price premiums and low cost carrier competition. Transportation Research Part E: Logistics and Transportation Review, 44(5), 864-882. http://dx.doi.org/10.1016/j.tre.2007.03.004

Jones, M. A., \& Suh, J. (2000). Transaction-specific satisfaction and overall satisfaction: An empirical analysis. Journal of Services Marketing, 14(2), 147-159. http://dx.doi.org/10.1108/08876040010371555

Keller, K. L. (1993). Conceptualizing, measuring, and managing customer-based brand equity. The Journal of Marketing, 1-22. http://dx.doi.org/10.2307/1252054

Keller, K. L., \& Lehmann, D. R. (2003). The brand value chain: Optimizing strategic and financial brand performance. Marketing Management, (May/June), 26-31.

Keller, K. L., Parameswaran, M. G., \& Jacob, I. (2011). Strategic brand management: Building, measuring, and managing brand equity. Pearson Education India.

Kotler, P., \& Armstrong, G. (2004). Principles of marketing. Upper Saddle River, Pearson Prentice Hall.

Lanza, K. M. (2008). The antecedents of automotive brand loyalty and repurchase intentions (Doctoral dissertation, UNIVERSITY OF PHOENIX).

Lassar, W., Mittal, B., \& Sharma, A. (1995). Measuring customer-based brand equity. Journal of Consumer Marketing, 12(4), 11-19. http://dx.doi.org/10.1108/07363769510095270

Lehmann, D. R., \& Srinivasan, S. (2014). Assessing Brand Equity Through Add-on Sales. Customer Needs and Solutions, 1(1), 68-76. http://dx.doi.org/10.1007/s40547-013-0002-8

Monroe, K. B. (1990). Pricing: Making profitable decisions (2nd ed., pp. 5294-5454). New York: McGraw-Hill.

Nam, J., Ekinci, Y., \& Whyatt, G. (2011). Brand equity, brand loyalty and consumer satisfaction. Annals of Tourism Research, 38(3), 1009-1030. http://dx.doi.org/10.1016/j.annals.2011.01.015

Netemeyer, R. G., Krishnan, B., Pullig, C., Wang, G., Yagci, M., Dean, D., ... Wirth, F. (2004). Developing and validating measures of facets of customer-based brand equity. Journal of Business Research, 57(2), 209-224. http://dx.doi.org/10.1016/S0148-2963(01)00303-4

Park, C. S., \& Srinivasan, V. (1994). A survey-based method for measuring and understanding brand equity and its extendibility. Journal of Marketing Research, 271-288. http://dx.doi.org/10.2307/3152199

Patterson, P. G., Johnson, L. W., \& Spreng, R. A. (1996). Modeling the determinants of customer satisfaction for business-to-business professional services. Journal of the Academy of Marketing Science, 25(1), 4-17. http://dx.doi.org/10.1177/0092070397251002

Ringle, C. M., Sarstedt, M., \& Straub, D. W. (2012). Editor's comments: A critical look at the use of PLS-SEM in MIS quarterly. MIS Quarterly, 36(1), iii-xiv.

Sattler, H., Völckner, F., Riediger, C., \& Ringle, C. M. (2010). The impact of brand extension success drivers on brand extension price premiums. International Journal of Research in Marketing, 27(4), 319-328. http://dx.doi.org/10.1016/j.ijresmar.2010.08.005

Sethuraman, R. (2000). What makes consumers pay more for national brands than for private labels: Image or 
quality. Marketing Science Institute Paper Series, 00-110.

Shen, L., \& Luo, C. (2013). An empirical study of luxury fashion brands consumption in China: Brand equity, consumer satisfaction and brand loyalty. International Conference on Business Computing and Global Informatization, Changsha, 2013, pp. 35-38.

Srinivasan, V., Park, C. S., \& Chang, D. R. (2005). An approach to the measurement, analysis, and prediction of brand equity and its sources. Management Science, 51(9), 1433-1448. http://dx.doi.org/10.1287/mnsc.1050.0405

Sweeney, J. C., \& Soutar, G. N. (2001). Consumer perceived value: The development of a multiple item scale. Journal of Retailing, 77(2), 203-220. http://dx.doi.org/10.1016/S0022-4359(01)00041-0

Tzeng, J. Y. (2011). Perceived values and prospective users' acceptance of prospective technology: The case of a career eportfolio system. Computers \& Education, 56(1), 157-165. http://dx.doi.org/10.1016/j.compedu.2010.08.010

Washburn, J. H., \& Plank, R. E. (2002). Measuring brand equity: An evaluation of a consumer-based brand equity scale. Journal of Marketing Theory and Practice, 46-62.

Woodruff, R. B. (1997). Customer value: The next source for competitive advantage. Journal of the Academy of Marketing Science, 25(2), 139-153. http://dx.doi.org/10.1007/BF02894350

Yoo, B., \& Donthu, N. (2001). Developing and validating a multidimensional consumer-based brand equity scale. Journal of Business Research, 52(1), 1-14. http://dx.doi.org/10.1016/S0148-2963(99)00098-3

Zeithaml, V. A. (1988). Consumer perceptions of price, quality, and value: A means-end model and synthesis of evidence. The Journal of Marketing, 2-22. http://dx.doi.org/10.2307/1251446

Zineldin, M. (2000). Total relationship management (TRM) and total quality management (TQM). Managerial Auditing Journal, 15(1/2), 20-28. http://dx.doi.org/10.1108/02686900010304399

\section{Copyrights}

Copyright for this article is retained by the author(s), with first publication rights granted to the journal.

This is an open-access article distributed under the terms and conditions of the Creative Commons Attribution license (http://creativecommons.org/licenses/by/3.0/). 